\title{
Um diplomata em defesa do princípio universal dos direitos humanos
}

Entrevista com José Augusto Lindgren Alves'

Por Gustavo Mesquita* https://orcid.org/0000-0002-6460-495X

A trajetória do embaixador brasileiro José Augusto Lindgren Alves ficou marcada pela longa atuação em organismos internacionais de controle dos direitos humanos. Durante os 35 anos de trabalhos realizados no Ministério das Relações Exteriores (MRE) e na Organização das Nações Unidas (ONU), entre as décadas de 1980 e 2010, a imbricação dos direitos humanos com temas sociais contemporâneos destacou-se como núcleo de suas preocupações. Ele foi o diplomata que criou o Departamento de Direitos Humanos e Temas Sociais do Itamaraty, experiência que o inspirou a participar a título pessoal do Comitê para a Eliminação da Discriminação Racial da ONU (CERD), órgão de controle da Convenção Internacional sobre a Eliminação de Todas as Formas de Discriminação Racial (ICERD). Depois de coordenar a delegação brasileira em conferências da ONU decisivas para a consolidação democrática de diversos países, foi ao longo de tão extenso percurso que o embaixador pôde conhecer profundamente as políticas antirracistas implementadas pelos Estados nacionais participantes da ICERD, dando a sua contribuição para o sistema internacional dos direitos humanos.

Recentemente, Lindgren Alves lançou É preciso salvar os direitos humanos (2018a), livro que expõe reflexões amadurecidas sobre a crise atual do sentido dos direitos humanos. Ao todo são seis livros de sua lavra, identificados com a preo-

* Fundação Getúlio Vargas, Rio de Janeiro, Brasil.

1. Entrevista concedida por ocasião da Conferência Brasileira de Estudos Políticos sobre os Estados Unidos, realizada pelo Instituto Nacional de Ciência e Tecnologia para Estudos sobre os Estados Unidos na Pontifícia Universidade Católica de São Paulo, de 25 a 28 de novembro de 2019. 
cupação não só de compreender, mas de defender aquilo que fundaria os direitos humanos: o progresso da igualdade com liberdade. Sua obra caracteriza-se pelo tom ensaístico, pouco afeito às marcações disciplinares, e interliga conhecimentos das ciências humanas e sociais com o objetivo de discutir o desenvolvimento e a situação atual dos direitos humanos.

Nesta entrevista com o embaixador, temos em mãos um conjunto de questões relacionadas com a sua trajetória e obra. Abordo assuntos que vão dos seus caminhos diplomáticos à sua crítica incisiva ao diferencialismo tão apreciado em nossos dias. Sendo o entrevistado figura de proa do movimento internacional pelos direitos humanos, suas propositivas palavras, emanadas da experiência, convidam à reflexão os que se preocupam com os rumos da vida democrática.

Gustavo Mesquita: Gostaria de começar a entrevista pela sua trajetória como diplomata brasileiro. Quais momentos você considera especiais?

José Augusto Lindgren Alves: Eu fiz o vestibular para o Instituto Rio Branco em 1967 e entrei em 1968. Encontrava-me no meio do curso quando veio o AI-5. Naquele regime de repressão, parecia constrangedor ser diplomata brasileiro, mas, depois de passar no concurso, não havia razões pessoais para desistir. Ao me formar, fui lotado, por acaso, numa divisão do Itamaraty que tratava do comércio com a Europa Oriental: Coleste. $\mathrm{O}$ trabalho exigia viagens para as feiras internacionais de que o Brasil participava na área. Pude conhecer, assim, tanto o amedrontador "mundo comunista", como algumas das fascinantes capitais europeias nos "trinta anos gloriosos", de pleno Estado de Bem-Estar e ampla liberdade.

O segundo momento relevante foi a oportunidade de trabalhar com um de nossos maiores homens públicos, o embaixador José Sette Câmara Filho, na Embaixada em Praga (antes eu servira em Viena). Sette Câmara, que então dividia seu tempo entre a Tchecoslováquia e a ONU (tanto a Comissão de Direito Internacional quanto a Assembleia Geral), e depois foi juiz da Corte Internacional de Justiça, foi, além de chefe e amigo, meu "professor de onU".

O período que mais veio marcar minha vida foi quando servi como conselheiro na Missão das Nações Unidas, em Nova York, de 1985 a 1988, trabalhando com direitos humanos. Depois disso, embora servindo em outros lugares, tendo defendido tese sobre o assunto, nunca me distanciei totalmente do sistema da ONU, nem dos direitos humanos. Sobre eles trabalho há 35 anos.

Se fosse destacar um momento especialíssimo, ocorreu na Conferência Mundial de Direitos Humanos, em Viena, de 1993, em que, na qualidade de delegado, 
assessorei o embaixador Gilberto Saboia no comitê de redação dos documentos. Lá o Brasil recebeu a maior aclamação a que já assisti - sem contar vitórias do futebol em Copas do Mundo.

GM: Em linhas gerais, como foi o percurso até a sua escolh a para compor o CERD?

JA: Nunca deixei o Itamaraty, nunca servi em gabinete de ministro, nem chefiei grande posto. Depois da Coleste, em Brasília, segui, como segundo secretário, para a Embaixada em Viena, depois Praga e Túnis. De volta a Brasília, fui subchefe da divisão que cuidava dos países de língua portuguesa na África e de toda a África Austral. O trabalho era interessante porque, desde o governo Geisel, a África havia adquirido prioridade em nossa política externa. Era particularmente delicado mostrar aos demais órgãos do governo, inclusive à Escola Superior de Guerra e à Escola Nacional de Informações, que, independentemente das respectivas ideologias, os países africanos gostavam do Brasil, vendo-nos como país mestiço e alternativa para a relação de dependência com o ex-colonizador. E que, para aproveitar esse ativo, não podíamos aproximar-nos do regime de apartheid da África do Sul. Graças a esse trabalho que ajudei a realizar, consegui ser removido para a Missão da ONU. De lá fui para a Embaixada em Caracas, logo para Windhoek, na Namíbia, onde acompanhei a independência e abri nossa Embaixada.

No final de 1990, chefiei a Divisão das Nações Unidas do Itamaraty. Com insistência ao longo de cinco anos, convenci o MRE a abrir um departamento para direitos humanos e temas sociais, de que fui o primeiro chefe. Nessas duas funções sequenciais, fui delegado e coordenador da participação do Brasil em todas as grandes conferências sociais da década de 1990: Viena, 1993, sobre direitos humanos; Cairo, 1994, sobre população; Copenhague, 1995, sobre desenvolvimento social; Pequim, 1995, sobre os direitos da mulher; Istambul, 1996, sobre assentamentos humanos. Igualmente nessa fase, pela primeira vez integrei, por eleição, órgão da ONU, com exercício a título pessoal: a antiga Subcomissão de Prevenção da Discriminação e Proteção de Minorias. Isso tudo me deu certa notoriedade na sociedade civil e na academia.

Em 1997, tive que sair do Brasil novamente. Fui cônsul geral em S. Francisco, de onde, em 2001, o então chanceler Celso Lafer chamou-me para retomar o trabalho da Conferência Mundial de Durban, contra o Racismo, de 2001. Digo "retomar" porque Lafer sabia que a proposta original da Conferência havia sido minha, na Subcomissão. Em 2002, já embaixador, transferiram-me para a Embaixada em Sófia. Foi nesse período que pleiteei ser designado candidato a uma das vagas para a América Latina no CERD. Como as sessões não eram permanentes, eu poderia desincumbir-me delas, em Genebra, na qualidade de perito, sem prejuízo da Embaixada na Bulgária. 
Isso me garantiria um pé no sistema da ONU, em tema com o qual já havia trabalhado. Eleito em 2002 e reeleito três vezes, permaneci no CERD dezesseis anos.

O CERD, creio importante assinalar, é comitê composto de dezoito "peritos" de origens e culturas diversas, para supervisionar a implementação da Convenção contra a Discriminação Racial (United Nations, 1965). Criado pela própria convenção, em 1965, e estabelecido em 1970, foi o primeiro dos denominados "órgãos de tratado". Seus membros, chamados "peritos”, são eleitos pelos Estados-partes da ICERD entre candidatos apresentados pelos respectivos governos que o desejarem, para exercer as funções a título pessoal, sem, portanto, representá-los, com mandatos de quatro anos, renováveis. Não há remuneração, apenas diárias e passagens pagas pela ONU. Reúnem-se em sessões de três ou quatro semanas, normalmente duas vezes por ano, no Escritório da ONU em Genebra, que garante os serviços de secretariado.

Se a candidatura ao CERD não foi longamente planejada - nenhuma candidatura para órgão de tratado ocorre com grande premeditação, pois depende da existência de vaga e apoio do Estado para inclusão na lista de concorrentes -, a decisão, no meu caso, tampouco foi casual. Eu soube da vaga quando me encontrava novamente em Genebra, em sessão preparatória para a Conferência de Durban, e havia, assim, voltado provisoriamente ao tema da discriminação racial. Solicitei pouco depois minha indicação ao MRE, que me deu seu apoio para o pleito. Nessa e em mais três vezes. Uma quinta oportunidade me foi oferecida em 2017, mas eu declinei, cansado e com dúvidas sobre a propriedade das propostas que vinham sendo formuladas naquele órgão.

Simultaneamente com a função de membro no CERD, servi, depois da Bulgária, como embaixador em Budapeste, representei a Aliança de Civilizações em Brasília, fui para Sarajevo, na Bósnia, onde abri Embaixada, e em Barcelona, onde fui cônsul-geral. Terminei o serviço público em 2016, mas permaneci mais dois anos como membro do CERD, em Genebra, e fui secretário executivo do Instituto de Políticas Públicas de Direitos Humanos do Mercosul, em Buenos Aires. Indicado no governo Temer e eleito em setembro de 2018, sou atualmente membro do Comitê Assessor do Conselho de Direitos Humanos da ONU, com mandato até 2021.

GM: Ao longo de sua atuação você enfrentou resistências por defender os direitos humanos? De que forma aconteceram? De onde vieram?

JA: Não propriamente por defender os direitos humanos. Sempre algum diplomata tinha que trabalhar nisso. Em Nova York, tive um pouco de resistências para algumas sugestões de voto, que Brasília relutava assumir naquele período de transição à democracia durante o governo Sarney. Mas isso era compreensível, e avançamos bastante. 
A atitude do Brasil perante os direitos humanos começou a mudar realmente no governo Collor, que se dispôs a dialogar com a Anistia Internacional, e no governo Itamar Franco, quando Fernando Henrique Cardoso era chanceler. Em 1993, na preparação para a Conferência de Viena, o Itamaraty acolheu seminário com ONGs de direitos humanos, para a definição de posições comuns. Eu era chefe da Divisão das Nações Unidas e coube a mim organizá-lo. Lembro-me de Paulo Sérgio Pinheiro, que não me conhecia, observar, com surpresa, num almoço de que participávamos: "Nossas posições são iguais!" Desde então ele e eu trabalhamos juntos muitas vezes, tornando-se o Núcleo de Estudos da Violência da Universidade de S. Paulo (NEv), que ele dirigia, nosso parceiro regular. É verdade que alguns colegas me chamavam em tom jocoso de "amigo das ongs". Mas não era nada grave, nem eles criavam obstáculos.

O que de mais sério aconteceu comigo, obrigarem-me a sair das funções de chefe do novo departamento, o de direitos humanos e temas sociais, quando eu menos esperava, não foi obra de opositores internos. Foi de aliados na causa, poderosos em outros órgãos. Devo reconhecer, porém, em compensação, que foi graças a meu trabalho com direitos humanos que cheguei a embaixador, nível máximo da carreira, quando havia quase perdido as esperanças.

GM: O que para você ésignificativo, em termos de conquista de direitos, de forma universal e para o Brasil em particular em relação à atuação do CERD no sistema internacional dos direitos humanos?

$J A$ : A ICERD é de 1965. Foi o primeiro instrumento jurídico adotado pela ONU para ser subscrito e ratificado voluntariamente por Estados, com base na Declaração Universal dos Direitos Humanos (United Nations, 1948). Inaugurou, portanto, o direito internacional dos direitos humanos, estabelecendo obrigações na matéria.

Na segunda metade da década de 1960, depois da superação das célebres leis Jim Crow do Sul dos Estados Unidos, que impediam os negros até de votar, e demais instrumentos racialmente discriminatórios norte-americanos, pensava-se sobretudo no problema do apartheid da África do Sul. Não foi somente o Brasil que, nos primeiros relatórios periódicos ao CERD, nos anos 70, dizia não abrigar legislação diferenciadora por raça, não precisando adotar leis ou medidas para cumprir o tratado. Criado em 1965 e estabelecido em 1970, o CERD fez logo ver a todos os Estados-partes que a discriminação pode ser velada, não baseada em leis ou na vontade dos governos, e que nenhuma sociedade é isenta de racismo. Aos Estados incumbe combater também essas manifestações, com ações de ordem variada, e descrevê-las, com seus efeitos, em relatórios periódicos, para avaliação e recomendações do Comitê. 
Os relatórios são instrumentos importantes também internamente, porque a própria feitura exige um esforço de tomada de consciência para problemas existentes e dificuldades de saná-los. Seu exame, por outro lado, propicia ao CERD opinar sem motivações políticas e sugerir ações sem que isso possa ser encarado como intromissão em assuntos internos. Ao fazer recomendações e ao promover a Convenção, o CERD divulga o que considera necessário no combate ao racismo. Ajuda, com isso, a popularizar práticas supostamente úteis, como a proibição legal de partidos racistas e propaganda de superioridade racial, levantamentos estatísticos desagregados das diferentes áreas sociais, criação de órgãos nacionais de controle, medidas especiais "ação afirmativa” - para segmentos historicamente discriminados, apoio a iniciativas não governamentais para grupos específicos e assim por diante. Para os interessados, todos os relatórios e todas as recomendações do CERD podem ser lidas nos sites da ONU, ou, mais recentemente, do Alto Comissariado para os Direitos Humanos².

O problema que vejo hoje é que suas recomendações, inspiradas no modelo americano, estimulam demais diferenças étnicas, como se desejassem separar as comunidades. Fazem, em menor grau, aquilo que mais combatíamos no regime do apartheid. Ressalto, porém, desde logo que essas recomendações não precisam ser seguidas. Os que não as observem in toto, como é o caso de países da Europa, têm a obrigação de apresentar relatórios, explicando também seus motivos.

Depois do regime militar, o Brasil levou muito tempo em atraso nos informes. Como pude comprovar na chefia da Divisão das Nações Unidas, isso se devia mais a dificuldades para o levantamento de dados pelo Itamaraty, desaparelhado com meios próprios, do que a displicência dos governos. Foi com recurso ao NEV para esse levantamento e primeira redação do texto que o Brasil logrou atualizar os relatórios em 1995, após interregno de 12 anos. Período de atraso igualmente longo o país está tendo novamente, desde 2004, em função de indecisões da Secretaria de Políticas de Promoção da Igualdade Racial (Seppir) para contratação de entidade capaz de preparar o informe. Segundo me foi explicado, a Seppir achava que as obrigações principais, senão exclusivas, seriam aquelas do Programa de Ação de Durban (United Nations, 2002). Embora eu tenha sabido que um novo relatório estaria pronto para apresentação, não sei como o Brasil poderá, no governo atual, atualizar seriamente essa obrigação, levando em conta que o período coberto corresponde a governos passados, repudiados como "comunistas".

Acho, francamente, que, no combate ao racismo, assim como em outras áreas que envolvem direitos, excessos inspirados no padrão norte-americano precisam ser revistos, inclusive no CERD. As discriminações têm crescido no mundo inteiro. Não quero 
dizer que esse crescimento se deva ao modelo adotado. As causas são mais profundas. Mas o modelo, fora de contexto, contribui com ações deslocadas, gerando reações cada dia mais fortes. Revisão de posturas precisa ser feita, com isenção, pelo movimento negro. Não se pode deixar que ela ocorra por iniciativa apenas dos governos.

GM: Podemos dizer que o Brasil exerceu liderança nas Conferências de Viena e de Durban a favor do fortalecimento dos direitos humanos? Gostaria que você contasse como foi a atuação da delegação brasileira nessas duas conferências mundiais.

JA: Podemos dizer e orgulhar-nos disso. Foi graças à atuação brasileira que a Conferência de Viena de 1993 constituiu o evento multilateral mais importante sobre os direitos humanos desde o fim da Guerra Fria. Seu documento final, a Declaração e Programa de Ação de Viena (United Nations, 1993), pormenorizado e abrangente, aprovado por consenso, foi todo negociado sob orientação e com intermediação de delegados brasileiros. Habituados a atuar como pontes entre maximalistas e opositores, entre Leste e Oeste, entre o Norte desenvolvido e o Sul em desenvolvimento, fomos nós, brasileiros, no Comitê de Redação (presidido pelo embaixador Saboia), com um grupo informal improvisado (chefiado por mim, com apoio de outros colegas), que propiciamos o entendimento obtido, em sessões prolongadas até a manhã. Já falei e escrevi tanto sobre isso e sobre os resultados da Conferência que me parece expletivo repetir (Lindgren Alves, 1994; Lindgren Alves, 2018b). Além de envolver outras áreas importantes, a Conferência de Viena reafirmou por consenso difícil a universalidade dos direitos humanos, confirmou a legitimidade da preocupação internacional com sua situação dentro de cada Estado, tratou com realismo as diferenças de culturas, deu impulso à criação do cargo de Alto Comissário do assunto na ONU.

Quanto à Conferência de Durban, de 2001, contra a Discriminação Racial, Xenofobia e Intolerância Correlata, até mesmo a proposta original foi brasileira, porque minha, a título pessoal, encaminhada na Subcomissão de Prevenção e Proteção de Minorias, em 1994. A Conferência em si teve a relatoria a cargo de nossa compatriota Edna Roland. Protelado e com objetivos excessivamente ampliados, o evento foi criticado por motivos alheios às questões propriamente raciais. Conseguiu, também graças à atuação do embaixador Gilberto Saboia, ter seu Programa de Ação adotado. O documento de Durban constitui, até hoje, a principal referência de ação para o movimento negro, no Brasil e no resto da América Latina.

Tanto em Viena quanto em todas demais conferências sociais da ONU na década de 90, as delegações do Brasil, respaldadas pela participação da sociedade civil, atuaram na conciliação de posições divergentes, propiciando fórmulas de endosso planetário. 
Somente para quem prefere a confrontação antidemocrática, a importância desse tipo de esforço pode ser questionada.

\section{GM: Qual o sentido dos direitos humanos no momento em que foram criados?}

JA: Historicamente, os direitos humanos foram criados contra o absolutismo monárquico ou estatal em geral e para garantir a liberdade individual. Tendo como precursoras declarações nos Estados Unidos e na França, como a da Virginia, enquanto ainda era colônia, seguida depois pela Declaração de Independência dos Estados Unidos com o Bill of Rights, e, mais influente ainda, a declaração francesa, de 1789, dos Direitos do Homem e do Cidadão, a ONU, recém-criada, deu início à preparação da Declaração de 1948. Nenhuma das anteriores, de autoria e alcance nacional, incluía as mulheres, os escravos e as minorias étnicas nesses direitos. A única internacional, com validade planetária e destinada a proteger do arbítrio todos os seres humanos, foi a Declaração Universal dos Direitos Humanos, adotada pela Assembleia Geral da ONU, em Paris, em 10 de dezembro de 1948. Assemelhadas, mas não iguais, há declarações regionais, como a africana, a islâmica, e, no âmbito da OEA, para todo continente, a Declaração Americana de Direitos Humanos (Organization of American States, 1948).

Quando de sua adoção, pouco após a Segunda Guerra Mundial, o objetivo principal da Declaração Universal era respaldar a paz, evitando a possibilidade de repetição de horrores como os do Holocausto dos judeus pelo nazismo. Seu sentido abrangente, registrado no preâmbulo pela ideia da "dignidade inerente a todos os membros da família humana”, dotados de "direitos iguais e inalienáveis”, é ressaltado no Artigo $1^{\circ}$ pelo entendimento de que "todas as pessoas nascem livres e iguais em dignidade e direitos". A isso se acresce o fato de a Declaração de 1948 ser o único documento internacional intitulado "Universal". A Declaração se aplica a todos os indivíduos, homens e mulheres, em qualquer situação, inclusive habitantes de colônias, candidatos a refúgio ou apátridas. Segundo a doutrina prevalecente durante muito tempo, os direitos nela consagrados constituem um mínimo divisor comum a ser observado por todos os Estados civilizados. Como esse mínimo nunca foi totalmente realizado, hoje quase não se repete a ideia.

$\mathrm{Na}$ prática, os direitos humanos costumam ser comparados ao mito grego de Sísifo. São pedras levadas ao topo da montanha, que, em seguida, desabam. Conquanto produtos históricos, sujeitos à evolução, direitos universais não são considerados "conquistas". Decorrem de supostos atributos intrínsecos, mas atualizáveis, reconstruídos com formato semijurídico para necessidades humanas imanentes, reconhecidos, violados ou negados. "Conquistas" nessa área, meros sinônimos de 
“avanços”, como eu próprio uso o termo, são obtidas, ou não, pelas políticas destinadas a promover seu respeito.

Encarados como última utopia da modernidade, metanarrativa para o progresso social-democrático, os direitos humanos tiveram enorme ascendência na década final do século passado, em período imediatamente posterior à Guerra Fria. No século XXI seu curso tem sido descendente, corroídos por fora, pelo neoliberalismo econômico, e amolecidos por dentro, por culturas que os violam ou modismos que os esvaziam.

Hoje os direitos humanos, como a paz e o progresso social, encontram-se gravemente ameaçados, pelo desgaste dos regimes liberal-democráticos, pelos populismos de direita e de esquerda, pela descrença popular na democracia, demonstrada em eleições de candidatos extremistas, pela revalorização de tradições anacrônicas, pela corrupção e violência generalizadas, pela asserção política de crenças religiosas fundamentalistas. Pior, e acima de tudo, os direitos humanos são agora ameaçados pela disseminação de uma nova ideologia de direita, ridícula e ameaçadora, determinada a se tornar hegemônica. Para espalhar o pavor e a dominação dos incautos, seus arautos dizem ver em toda parte a "conspiração globalista" de um elaborado "marxismo cultural", baseado em Gramsci e na Escola de Frankfurt, coordenado pela ONU. Ensinados sem debate e difundidos, tais absurdos encontram terreno fértil na cabeça de gente ressentida, usuária assídua da internet, que os repete como fatos incontestes.

GM: Você discute o deslocamento do principio universal dos direitos humanos para os particularismos das identidades várias em seus estudos mais recentes. Gostaria que abordasse essa questão tendo por base as politicas de identidade, as minorias étnicas, o multiculturalismo, ou seja, o diferencialismo marcante nas politicas atuais de direitos bumanos.

JA: Desde os anos 60, a questão da identidade comunitária adquiriu relevo especial na luta dos negros norte-americanos pela concretização dos direitos civis. Concomitante a ela, com lógica assemelhada, os nativos, os hispânicos, os asiáticos passaram a adotar a mesma atitude, de valorização das respectivas identidades. A postura foi seguida também, com adaptações, pelas mulheres, no "feminismo da diferença” (após o "feminismo da igualdade"), pelos homossexuais, que eu me lembre, pela assunção do velho xingamento "queer" (“bizarro”, no Brasil, “veado”), antes mesmo da primeira formação LGBT, pelos grupos “diferentes” de qualquer tipo. Na área internacional, na ótica dos direitos humanos, foi sobretudo depois da Guerra Fria e da Conferência de Viena que a autoidentificação como pertencimento passou a ser ressaltada como essencial à pessoa, e a identidade foi incorporada na reivindicação de direitos. 
A expressão "multiculturalismo" começou a ser usada no Canadá, sem sentido racial. O país adotou, em 1988, uma norma chamada Canadian Multiculturalism Act, destinada a apaziguar o separatismo do Québec, permitindo o uso do francês como língua própria, sem proclamação de independência pela província - que quase chegou a ocorrer. Expandida semântica e geograficamente, a ideia foi acolhida nos Estados Unidos e incorporada na academia, com respaldo teórico de intelectuais não marxistas, sendo mais famoso o canadense Charles Taylor (1994).

Quando a expressão chegou ao Brasil como modismo político e acadêmico, no final dos anos 80 , grande parte dos que a usavam pensavam que ela consagrava a multiplicidade de aportes que compunham culturas sincréticas, como a brasileira, conferindo igual valor a todas as matrizes. Por essa linha, estariam sendo resgatadas, em tendência reminiscente de Gilberto Freyre ([1933] 2006) no Casa-grande \& senzala, mas sem atenuação dos males do escravismo e do colonialismo português, posições altaneiras para os elementos africanos e indígenas na formação da nacionalidade. Mas isso era um ledo engano. A prática do multiculturalismo que se espalhava tinha aproximação mais real, muito antes do uso desse termo, com o sistema colonial inglês, especialmente na Índia, para manter os nativos separados dos colonizadores. Lembrava a fundamentação teórica do sistema do apartheid e se aparentava, de fato, com o sistema segregado norte-americano, cujos aportes não-brancos não se pretendia integrar. Daí a substituição da metáfora do melting pot nos Estados Unidos, que nunca assimilou o contingente negro, pela do "mosaico" de peças adjacentes, compondo um todo harmônico.

Esse modelo norte-americano, que, com ações afirmativas, havia propiciado a elevação econômica dos negros nos Estados Unidos, mas cujos efeitos poderiam ter outras consequências alhures, foi o que predominou, inclusive nas recomendações do CERD. Adotado pelos militantes do movimento negro, impôs-se aos poucos no Brasil e nos demais países da América Latina, mas não nos países europeus, nem mesmo na Inglaterra. Esta, tal como a França, vinha enfrentando o problema das crispações comunitárias, especialmente islâmicas, que às vezes explodiam em motins urbanos violentos, aparentemente inexplicáveis, como na queima de veículos, muitos do quais pertencentes às próprias minorias.

A interpretação europeia, baseada na própria experiência, era de que o reconhecimento das "diferenças comunitárias", com adoção de medidas específicas para proteger as minorias como "direitos inalienáveis", tendia a incrementar o separatismo comunitário e o racismo da maioria. Afinal, foi na Europa, antes dos Estados Unidos com Trump, que a extrema direita começou a ganhar eleições, com líderes que usavam o discurso dos "direitos dos cidadãos nacionais autênticos", contra imigrantes e filhos de imigrantes, compatriotas judeus, negros e de outras etnias. 
Hoje a situação predominante é tal que o ativismo dos direitos humanos parece dedicar-se exclusivamente aos direitos de minorias. Com isso os direitos humanos perderam sua força moral categórica, acima de outros direitos, de titularidade restrita, às vezes até expletivos. Pior, perderam a popularidade ampla de que desfrutaram nos anos 90, passando a ser vistos como algo despiciendo, uma bobagem que só interessa a nefelibatas e militantes políticos "de esquerda".

Para resumir ainda mais essa história, a que aludo também em outras respostas, para mim, políticas são políticas, não podem ser confundidas com a proteção dos direitos fundamentais de todos. Os militantes que se emprenham na obtenção de medidas voltadas exclusivamente para comunidades ou minorias que delas necessitem por força das circunstâncias, podem e devem fazê-lo. Repito para que fique bem claro: podem e devem fazê-lo. Não devem, nem podem, porém, para tudo invocar a categoria superior dos direitos humanos, inaugurada em 1948. Estes, como os direitos à vida, à liberdade e à segurança da pessoa, primeiros reconhecidos na Declaração Universal, são instrumentos jurídicos preciosos na luta democrática para enfrentar ditaduras. Não foram reconhecidos como fundamento da paz e da segurança para respaldar reivindicações secundárias ou, até, questionáveis, como o expurgo de livros com linguagem hoje considerada inapropriada (Othelo, de Shakespeare, Huckleberry Finn, de Mark Twain, Caçadas de Pedrinho, de Monteiro Lobato etc.), a censura feminista ou racialista a obras de arte (La maja desnuda, de Goya, Lolita, de Nabokov, Iracema, de José de Alencar etc.), a oferta de banheiros específicos para homossexuais ou para cada variação de LGBTIs, ou a mensuração da espessura dos colchões em dormitórios de trabalhadores para a identificação de "formas de escravidão". Há que manter um mínimo de realismo ante problemas mais abrangentes e urgentes nas sociedades atuais.

GM: Em nossos dias ainda há o debate, acalorado desde a Segunda Guerra Mundial, sobre o racismo na sociedade brasileira. Como você entende a questão racial no Brasil? Quais referências foram mais significativas para o seu entendimento dessa questão?

JA: A questão racial brasileira é vinculada ao sistema escravista por cor, herdado do período colonial e mantido pelo Império independente, abolido sem alternativas de vida para as vítimas liberadas. Mas todos esses fatos, reais, tendem a ser interpretados de maneira enviesada e simplista.

É comum dizer-se, por exemplo, que a escravidão pela cor foi invenção de Portugal no período expansionista. Sem precisar repetir que a escravidão entre negros já existia na África, quase não se fala da escravidão de africanos pelos árabes, que durou treze séculos. Ela também era sistemática, envolvia o tráfico com chefes locais 
e incursões de captura, assim como um tráfego tão cruel e mortífero como o dos navios negreiros no Atlântico: travessias do deserto a pé, com correntes, mortes de sede e inanição, com reexportação frequente dos sobreviventes para a Península Arábica. Quem primeiro me perguntou sobre o motivo da ausência de menção a essa predecessora do tráfico transatlântico nos documentos de Durban foi um professor negro respeitável de universidade carioca. Assim como foi em texto de professor negro, muito merecidamente influente, Kabengele Munanga (2006), que primeiro li sobre esse assunto, por sua vez chamado de "genocídio ocultado" pelo historiador senegalês Tidiane N’Diaye (2009). A razão da omissão me parecia evidente: não era politicamente correto tocar no assunto.

A escravidão sistêmica foi utilizada por praticamente todos os povos, sendo os escravos, geralmente apreendidos em guerra, objeto de lucro, diversão e luxúria, uso militar ou doméstico e fator de produção econômica. Da mesma forma, quase não se menciona no Brasil o tráfico pelos ingleses, cujo puritanismo não os impediu de tornar-se grandes traficantes, no século XVIII, desse "material” por eles chamado de black ivory. Não quero com isso dizer que os portugueses tenham sido mais brandos, nem piores. Portugueses e brasileiros usaram do sistema mais intensamente e por mais tempo no Brasil, não porque fossem mais racistas, mas porque os escravos eram a força laboral propulsora de sua economia, como no Sul dos Estados Unidos.

Digo, sim, que não faz muito sentido condenar simplisticamente, com olhos moralistas de hoje, a origem certamente violenta da miscigenação brasileira. Sei, pelos historiadores mais sérios, que, extraídos de uma população europeia minúscula para viver em territórios gigantes, os colonizadores portugueses não dispunham de mulheres brancas, tendo a Coroa e as autoridades enviadas apoiado a mestiçagem desde o início do povoamento. Algo semelhante seria inconcebível para os puritanos ingleses, peregrinos que emigravam com suas famílias para escapar de perseguições religiosas.

Martim Afonso de Sousa, primeiro com a missão de povoar a terra descoberta em 1500, partiu para o Brasil, em 1530, com 400 homens e nenhuma mulher a bordo. A primeira esposa trazida foi Dona Brites, casada com Duarte Coelho, donatário da capitania de Pernambuco, em 1535. Foi ele, Duarte Coelho, com apoio de Dona Brites, quem primeiro promoveu o casamento religioso entre portugueses solteiros e índias, depois incentivado também pelos jesuítas, para "terminar com o pecado". Foi também Duarte Coelho, fundador de Olinda, quem primeiro importou negros da África, dada sua experiência cultural agrícola, em substituição aos indígenas extrativistas, escravizados e livres, para trabalhar na lavoura.

É absurdo questionar nosso caráter sui generis, sincrético e mesclado desde cedo, malgrado o abuso que o sexo entre senhores e escravas possa ter representado. Tam- 
pouco faz sentido insistir que fomos "o último país a abolir a escravidão". Conforme vi e examinei no CERD, os últimos foram países africanos, nas décadas de 1970 e 1980. No CERD encontrei um ex-escravo negro da Mauritânia morena, cuja situação recordava a do Brasil. Libertado pela lei, em 1981, vivia com os ex-senhores nas mesmas condições de antes. O sistema abolido na Constituição da Mauritânia, assim como na do Brasil de 1888, não fora erradicado na prática, nem nas mentes. Para uns era normal ser escravo, para outros, permanecerem senhores. Sem qualquer alternativa econômica, sem recursos para viver, os libertos não chegam a ser livres. E a situação continua assemelhada indefinidamente, se não houver reformas efetivas com medidas para a incorporação dos miseráveis ao "mercado". Não surpreende que a venda de pessoas em leilões públicos tenha ressurgido no interior da Líbia, em conflito de clãs interminável e bombardeada pelo Ocidente em "intervenção humanitária”.

No Brasil, o racismo é um compósito de classe, cor e aparência. Sem o cultivo do ódio, como nos Estados Unidos, a "cordialidade" brasileira ignora a pobreza e despreza o socialmente inferior. $O$ fenômeno da marginalização dos economicamente irrelevantes se encontra agravado, inclusive nos países mais ricos, legitimado pelas ideias neoliberais globalizadas desde o fim da Guerra Fria. O pobre não é visto como gente, titular de direitos fundamentais iguais, como o escravo de antes, é visto desprovido de alma e religiosamente pagão. Pode ser abandonado enquanto não representa ameaça. Problema é quando consegue ultrapassar a miséria e passa a competir com o senhor. É a situação que estamos vivendo de maneira ampliada. Graças às ações afirmativas e outras medidas, o negro brasileiro começa a ser competidor. De um lado a rejeição majoritária aumenta, de outro, a hipersensibilidade aflora, e cobranças se radicalizam.

O Brasil sempre foi racista. Nunca teve, contudo, uma Ku Klux Klan ou milícias supremacistas. Não conheço em nossa história movimentos organizados e aceitos de linchadores de negros por serem negros, nem "Panteras Negras" violentos contra brancos ou "Nações do Islã" separatistas. O que há nessa esfera agressiva é novo, de imitação, grupelhos racistas, contra nordestinos de qualquer cor em S. Paulo, neonazistas rejeitados pelos correligionários arianos que se estão sentindo mais fortes. Sem a cultura regular de ódio, importada dos Estados Unidos, apesar das disparidades econômicas, éramos mais integrados como população brasileira. Violência, discriminação e medo atingem todos, começando pelos mais pobres.

Para completar a resposta, assinalo minha rejeição à ideia de que o racismo disfarçado é pior do que o racismo discriminador assumido. Ninguém que tenha visto de perto o funcionamento do apartheid, na África do Sul e na Namíbia, pode compartilhar tal visão. Encaro-a apenas, e a contragosto, como recurso de mobilização. Não se pode equiparar a indiferença elitista ou preconceitos ferrenhos ao impedimento 
legal de permanecer na cidade, muito menos morar e viver nela, após 4 horas da tarde (caso de Windhoek, às vésperas da independência, que afetava até funcionários da futura Embaixada), à tipificação criminal do sexo entre adultos de raças diferentes, à proibição de coabitação sob o mesmo teto, à interdição do casamento inter-racial. Preconceitos e indiferença per se não levam à denegação constitucional de cidadania jurídica a pessoas naturais do mesmo sítio. Isso sim é literalmente sistêmico.

Em lugar do multiculturalismo na moda, creio melhor na mestiçagem não forçada e nos sincretismos de cultura para equacionar o problema. Se todos somos meio brancos, meio negros, na formação e na pele, não temos porquê, nem com quê, discriminar nossos iguais meio diferentes. É preferível tentar integrá-los realmente. Mas isso não pode ser carro-chefe da extrema direita, que nada de positivo vai querer fazer na matéria.

GM: Em nossos dias ainda há uma visão mais ou menos difundida de que o Itamaraty nega o racismo brasileiro e suas consequências sociais. Como o senhor avalia essa percepção?

JA: Não acredito que "o Itamaraty” negue o racismo brasileiro. Que eu saiba, isso não ocorria desde o início do período militar, quando predominava o mito do Brasil como democracia racial e poucos pensavam no assunto. No CERD, vi a delegação brasileira, em 1997 e 2004, reconhecer claramente as dificuldades sociais ligadas à discriminação racial, atual e estrutural, ao apresentar seus relatórios. Se a posição mudar em futuro próximo, não refletirá convicção da maioria dos colegas na ativa. Tampouco as mudanças de agora correspondem a posições da maioria.

A visão citada não me surpreende. Deve advir de impressão comum, mas equivocada, inclusive do movimento negro, que insiste em dizer que "o Itamaraty sempre foi racista”. Tal visão era fácil de se impor, tendo em conta a tradição aristocrática da diplomacia em todos os países, especialmente na Europa e no Império do Brasil, escravista.

O Itamaraty sempre foi uma instituição de elite, em todos os sentidos. Eu também achava que não entraria. A fama de que o vestibular era dos mais difíceis afugentava, e ainda amedronta, candidatos de todas as cores. A exigência de domínio de línguas, imprescindível às atividades da profissão, constituía, sem dúvida, uma barreira seletiva, sem critério racial. Os exames sempre foram realmente difíceis. Requeriam base sólida para a qual o ensino médio no Brasil não era suficiente. Eu próprio estudei na Cultura Inglesa, na Aliança Francesa e em curso pré-vestibular especializado. Tudo isso representava empecilho para compatriotas pobres, por mais igualitários que se dispusessem a ser os concursos.

É evidente que racistas sempre houve no Itamaraty, como em qualquer outro órgão ou profissão. A maioria dos diplomatas era sim elitista, alguns até arrogantes 
com os demais servidores, independentemente de cor. É possível que preferissem no foro íntimo não abrir socialmente a carreira. Mas isso eu nunca ouvi da boca de quem quer que fosse. Quase todos tinham o comportamento típico do branco brasileiro, paternalista "cordial" e declaradamente consciente de sua ascendência mestiça. Há uma história ilustrativa da época do chanceler Azeredo da Silveira. Quando, uma vez, creio que nos Estados Unidos, foi cobrado por não se ver nenhum negro em delegação por ele chefiada, sua réplica foi expressiva: "E você vê algum branco?"

A situação mudou bastante desde os anos 90. Lembro que cheguei a sugerir a lideranças do movimento negro recurso à empresa privada para o financiamento de bolsas a jovens que pretendessem fazer o concurso, habilitando-os para os exames em igualdade de condições. Creio que algo desse tipo chegou a ocorrer, não sei se com financiamento estatal ou privado. Não é criação de meu tempo na área, mas sei que o Instituto Rio Branco há anos mantém cotas. Hoje temos diplomatas negros em posições importantes, inclusive de chefia, não de ícones, em Brasília e no exterior. Pena é que a carreira brasileira, em processo começado há alguns anos, se encontre tão destroçada!

O problema da pobreza no Brasil não está superado, nem o será nas condições vigentes, mas ele não atinge exclusivamente negros e outros segmentos diferenciados. As disparidades permanecem imensas. E as novas camadas de classe média, ditas "emergentes", não ajudam, imitadoras de estilos e comportamentos alheios.

Quanto ao racismo brasileiro, como manifestação de preconceito e indiferença classista, ele existe sim e está se agravando no cenário cotidiano de provocaçôes, ignorância e simplismo, fenômenos banalizados pelo uso compulsivo de smartphones e redes sociais. Eles não são, aliás, particularidades brasileiras.

GM: Você acredita que as politicas de identidade são importantes para determinadas sociedades, sobretudo as dos paises que conseguiram independência há menos tempo, a exemplo dos paises africanos e caribenhos?

JA: Foram as identidades que criaram as nações atuais. Mas a luta pela nacionalidade independente no período romântico tinha um sentido humano emancipatório, difícil de ser negado totalmente. Ainda que os Estados-nações criados com base na identidade tenham produzido e exportado opressões sob novas formas, são eles os primeiros responsáveis pela observância do Direito e pela promoção dos direitos humanos.

Tendo em conta que o Holocausto nazista foi contra os judeus da Alemanha, excluídos do "direito de ter direitos", como notou Hannah Arendt (2007), vê-se que os direitos humanos devem defender também os diferentes. Aí surge logo uma questão importante. Seriam os judeus "diferentes"? Não seriam eles também criadores e 
divulgadores importantes da grande cultura alemã? Não eram culturalmente alemãs figuras extraordinárias como Einstein, Mahler, Stefan Zweig? Ou os judeus foram vistos como "diferentes" porque os nazistas buscavam "bodes expiatórios" para as dificuldades alemãs? Não quero dizer, como Sartre, mas de maneira simplista, que judeus são aqueles que os outros consideram judeus. O judaísmo é real e imanente, não somente como religião. Seu cimento comunitário mantém os judeus arraigadamente judaicos desde as perseguições narradas no Velho Testamento. Mas nada de diferencial imanente, nem mesmo a religião, impedia os judeus de serem alemães. Como os judeus do Brasil são brasileiros, como eu.

No CERD, ao ver a situação africana, senti de perto o absurdo de se impor o modelo americano de luta contra o racismo a todos. Em nome do multiculturalismo, o Comitê, contra minha vontade, cobra estatísticas desagregadas por etnia em todos os setores. Para isso é necessário, além de disponibilidade de recursos, que os Estados reconheçam como minorias étnicas todos os grupos de população no território. Reconhecer etnias na África é legitimar velhas tribos que digladiavam entre si. Conferir-lhes direitos especiais agora é promover novas guerras, inviabilizar a criação de nacionalidades abrangentes, como desejam os governos. A própria África do Sul de Mandela, pós-apartheid, com preferências raciais oficialmente invertidas, além de criminalidade espantosa, maior que a atual do Brasil, tem rejeição aos de fora. Na disputa por emprego e sustento, negros agridem outros negros, imigrantes do Zimbábue e outros países vizinhos, inclusive passando-lhes pela cabeça pneus em fogo como colares de ódio.

O Caribe é outra história. Lá quase só existem negros. Os brancos locais são pouquíssimos. Ainda assim, ou por isso, os caribenhos são líderes de cobranças de reparações das metrópoles pela escravidão do passado. Neles se encontram os primeiros vestígios da onda do "lugar de fala". Logo depois da Conferência de Durban, realizou-se na Jamaica um grande encontro de ONGs para avaliar o evento. Dele foram excluídos os brancos. $\mathrm{Na}$ época, tal atitude racista foi repudiada no CERD.

Para não fugir ao espírito da pergunta, entendo que os negros de países como o Brasil têm direito pleno de valorizar e seguir a cultura ancestral que queiram, assim como os indígenas, as suas. Como têm os judeus, os descendentes de eslavos, italianos, japoneses, árabes, alemães, espanhóis, portugueses etc. Para isso não é necessário desvalorizar os demais. Nada impede que eles próprios e seus filhos sejam brasileiros “da gema”. Desprezar a história de todos para valorizar outro lado é igualmente incorreto. Reduzir Machado de Assis para destacar Lima Barreto é bobagem. Depreciar a Princesa Isabel, o abolicionismo, Nabuco, a força de Castro Alves, é um crime, ou, melhor, suicídio. Não pode um progressismo falso, segregador, pós-moderno, propiciar à direita a bandeira de evitar essa morte. A Argentina de esquerda soube 
apreciar a contento o muito mais problemático gênio de Jorge Luiz Borges.

Em 1990, a Tempo Social da usp publicou um texto excelente de Antônio Flávio Pierucci (1990) com valor premonitório: Ciladas da diferença. Nele, Pierucci assinala que a diferença é valor da direita, que a esquerda vinha incorporando, com risco de efeito bumerangue. Depois desse artigo, os alertas desse tipo quase desapareceram, vistos como politicamente incorretos. A maioria dos analistas, como os jornalistas, artistas, espetáculos e mídia comercial, passaram a endossar obsessivamente o discurso diferencialista, louvando o pertencimento a grupos não majoritários como um desafio indignado. Alertas ficaram por conta de autores de centro ou provocadores vários, que chamavam atenção para as diferenças que passam do vitimismo à afirmação de superioridade, ameaçando os demais e gerando reações fortes. Sem falar na reapropriação do "direito à diferença” pela direita retrógrada. Tais alertas permaneceram isolados um bom tempo.

Depois da publicação do livro do Mark Lilla (2017), The once and future liberal, sobre o afundamento eleitoral da esquerda liberal norte-americana desde que optou pelas “identidades”, os alertas vêm-se tornando frequentes. De minha parte, eu, como universalista ferrenho, começo a sentir-me, talvez, menos isolado, embora ansioso e aflito, diante dos efeitos bumerangue já espalhados pelo identitarismo de esquerda. Prenunciados no Brasil por Pierucci, os efeitos são hoje assustadoramente sentidos, na piora do racismo, na irritação com os defensores de direitos das minorias, na repulsa comum ao discurso dos direitos, na eleição de políticos considerados "azarões" das disputas, popularizados por grosserias e ofensas a tudo que lhes pareça intelectual, acadêmico, culturalmente de esquerda, "politicamente correto".

GM: Atendo-se à sua trajetória diplomática e às principais ideias presentes em seus estudos, como podemos entender as suas posições no espectro politico? Podemos dizer que vocêpertence ao centro? Em relação às suas posições, qual seria o sentido do movimento pelos direitos humanos no mundo contemporâneo?

JA: Uma das características da extrema direita agora é roubar o discurso dos outros. Acho que a esquerda tampouco fica bem na matéria.

Por definição, a direita considera as desigualdades inerentes à condição humana, não havendo como mudá-las. A esquerda sempre achou o contrário: as desigualdades existem contingentemente, por obra do sistema e dos homens, cabendo, portanto, mudá-los. A esquerda falava em revolução como meio para mudar o sistema. Hoje quem fala em revolução é a extrema direita, para chegar ao poder e voltar ao passado. Os direitos humanos surgiram para modificar os sistemas. Foram usados e abusados pelos liberais durante toda a Guerra Fria para criticar comunistas. 
Hoje a situação inverteu-se: "comunista" é rótulo para aqueles que defendem minorias e direitos humanos. Antes o "progressista" lutava pelo progresso com igualdade entre todos. Hoje "progressista" é quem luta pela identidade de poucos. "Progresso" virou, para a esquerda pós-colonial pós-moderna, ficção da modernidade eurocêntrica, branca, homofóbica, machista e dominadora. Melhor é voltar ao passado das tradições sempre que não europeias. Burca, xador e véus ditos muçulmanos não são mais imposições opressivas de culturas masculinas. São "direitos" da mulher, de se apresentar como queira. Misógina, machista e pedófila é só a Igreja Católica. Eu fico com os velhos direitos humanos, universais, de todos. São a utopia em que insisto. Não tenho opção. São eles que, como explicava T. H. Marshall (1967) em estudo sobre a cidadania, respaldaram os trabalhadores europeus na luta por seus direitos econômicos e sociais. São eles que ainda podem garantir continuidade às frágeis democracias existentes.

Para a esquerda, ou centro-esquerda, em especial, é que falo. Ou ela encara a verdade, que seus objetivos visíveis em matéria de direitos são secundários diante da violência que assola todos, dão munição à direita pela irritação que provocam, ou, se não o fizer, continuará perdendo eleições. Mais do que modificações linguísticas e de hábitos arraigados pela "capilaridade do poder”, na expressão de Foucault (1979), o "politicamente correto" é, hoje, como já tendia a ser desde antes, uma cobrança abusiva. Não denunciar esse fato para que a esquerda se emende, para que os ativistas de direitos entendam os exageros que isolam, é aceitar a intolerância com medo de soar politicamente incorreto.

GM: Sabemos que a democracia liberal tem sofrido ataques ao redor do mundo. Você vê alternativas para a democracia liberal num horizonte próximo?

JA: Não vejo. Tampouco vejo motivos de grande esperança para ela.

Portugal, exceção positiva, com governo de centro-esquerda e bons resultados sociais e econômicos num cenário europeu adverso, não tem estatura para servir de modelo. A Finlândia, com governo recém-eleito, idem. A Espanha, mais significativa, que pode talvez se desmembrar para sempre, tem agora um governo de aliança socialdemocrata graças à abstenção dos deputados nacionalistas da Catalunha, é periclitante. A União Europeia, longamente modelo de região para o Mercosul e toda a América Latina, já perdeu o Reino Unido. Se este se der bem separado, há de inspirar muitos outros. O Leste Europeu inteiro é de direita extremada. Foi na Hungria que Viktor Orban, há uma década, forjou a expressão "democracia iliberal”, dando-lhe aplicação consistente na prática. Nos Estados Unidos, Trump, inocentado pelo Senado num bobo processo de impeachment, tem forte possibilidade de 
reeleger-se. Na América Latina, a democracia, que nunca foi muito estável, enfrenta graves sobressaltos sociais e políticos. Sem falar no Brasil, ainda pasmo com a vitória da extrema direita, que finge esquecer agora o que o candidato dizia.

Pensar que a direita ascendente, do inglês Boris Johnson, do indiano Modi, do filipino Duterte e quejandos, possa restaurar confiança no jogo liberal-democrático é sonho. Enquanto esses políticos personificam, ao contrário, ameaças visíveis, são os votantes anônimos que os elegem. Não é preciso recorrer a Levitsky \& Ziblatt (2018) para notar que o retrocesso atual “começa nas urnas”. Dizer, como se tem dito no Brasil de 2019 e 2020, que o que vem ocorrendo no país em matéria de regressão de conquistas sociais, direitos de minorias, mulheres e políticas públicas, é obra do "grupo ideológico" do governo é tapar o sol com a peneira. O candidato a presidente dizia claramente, e repetia, que iria seguir essa linha. Talvez não acreditassem nele.

O discurso doutrinário da extrema direita de hoje, que se articula internacionalmente, é mais parecido com o anti-iluminismo do fascismo histórico ítalo-alemão do que o dos regimes militares da América Latina. A par de imitações de líderes agressivos, seus mitos são transmitidos como fatos inquestionáveis, em cursos via internet com ampla audiência. Difundidos pelos meios de comunicação eletrônica ao alcance de todos, os chavões são repetidos por seguidores infinitos, a maioria dos quais não sabe o que está dizendo. Tanto quanto a má fé de pretensos filósofos, a ignorância ressentida e "empoderada” dá medo.

Vendo o filme belíssimo J’accuse ${ }^{3}$, sobre o célebre Caso Dreyfus - obra cuja celeuma em torno das motivações pessoais do diretor, Roman Polanski, desconsidera a oportunidade mais ampla do tema -, lembrei-me do caso Vladimir Herzog, no Brasil, morto em 1975. Oficialmente dado como suicídio, em estabelecimento tenebroso da repressão hoje elogiada como "patriótica”, a fotografia tirada na ocasião mostra o "auto-enforcado" pendurado pelo pescoço de janela basculante da sala, tão baixa que suas pernas são vistas dobradas no chão. Torturas se confirmaram depois pelas marcas do cadáver. $O$ fato foi tão chocante que nem o general-presidente o absorveu satisfeito, levando-o a acelerar a distensão desejada. O presidente era Ernesto Geisel, firme reiniciador da política externa independente, que durou até 2018, condizente com o povo heteróclito, as forças armadas abrangentes e o tamanho gigantesco do Brasil, única capaz, inclusive, de nos garantir a Amazônia. A distensão foi avante; a política independente, orgulho dos brasileiros, que dava importância ao país entre os outros, e que se supunha de Estado, logo permanente, encerrou-se.

Casos semelhantes aos de Dreyfus, de Herzog, da política externa brasileira, repetem-se atualmente alhures, com outros atores, outras vítimas, outras áreas e instituições

3. J’Accuse (2019), direção de Roman Polanski. Paris, Califórnia Filmes. 
consagradas, em tantos lugares do planeta, que mal causam escândalo. Banalizam-se e são esquecidos. Constituem, porém, sintomas alarmantes da situação de perigo em que se encontra a democracia com liberdade no mundo. Ela me faz recordar a provocação de Zizek aos que, indiferentes, ricos e felizes nas condições presentes, encaram com otimismo as perspectivas unilaterais que vislumbram: "Certifiquem-se de que a luz no final do túnel não é o farol de um trem em sentido contrário”.

Não acredito, mas temo, profundamente, que o trem já tenha chegado. Esperemos que não se instale como estação terminal permanente.

\section{Referências Bibliográficas}

Arendt, Hannah. (2007), Origens do totalitarismo. São Paulo, Companhia das Letras.

Foucault, Michel. (1979), Microfísica do poder. Rio de Janeiro, Graal.

Freyre, Gilberto. (2006), Casa-grande \& senzala: formação da família brasileira sob o regime de economia patriarcal. $1^{\text {a }}$ edição 1933. São Paulo, Global.

Levitsky, Steven \& Ziblatt, Daniel. (2018), How Democracies Die. New York, Broadway Books.

Lilla, Mark. (2017), The Once and Future Liberal: After Identity Politics. New York, Harper. Lindgren Alves, José Augusto. (1994), Os direitos humanos como tema global. São Paulo, Perspectiva.

Lindgren Alves, José Augusto. (2018a), É preciso salvar os direitos humanos. São Paulo, Perspectiva.

Lindgren Alves, José Augusto. (2018b), A década das conferências (1990-1999). 2a ed. Brasília, Funag.

Marshall, T. H. (1967), Cidadania, classe social e status. Rio de Janeiro, Zahar.

MunAnga, Kabengele. (2006), "Algumas considerações sobre 'raça', ação afirmativa e identidade negra no Brasil: fundamentos antropológicos". Revista USP, 68: 46-57.

N’Diaye, Tidiane. (2009), Le génocide violé: enquête historique. Paris, Gallimard.

Organization Of American States. (1948), American Declaration of the Rights and Duties of Man. http://www.oas.org/en/sla/. Consultado em 13/02/2020.

Pierucci, Antônio Flávio. (1990), “Ciladas da diferença”. Tempo Social, 2 (2): 7-33.

TAYLOR, Charles et al. (1994), Multiculturalism: Examining the Politics of Recognition. Princeton, Princeton University Press.

United Nations. (1948), Universal Declaration of Human Rights. New York, Un. https:// www.un.org/en/universal-declaration-human-rights/. Consultado em 13/02/2020.

United NATiONs. (1965), International Convention on the Elimination of All Forms of Racial Discrimination. New York, UN. https://www.ohchr.org/EN/ProfessionalInterest/Pages/ CERD.aspx. Consultado em 13/02/2020. 
United Nations. (1993), Vienna Declaration and Program of Action. New York, un. https:// www.ohchr.org/EN/ProfessionalInterest/Pages/Vienna.aspx. Consultado em 13/02/2020. United Nations. (2002), Durban Declaration and Program of Action. New York, Un. Disponível em https://www.ohchr.org/EN/ProfessionalInterest/Pages/UniversalHumanRightsInstruments.aspx. Consultado em 13/02/2020.

Texto recebido em 16/2/2020 e aprovado em 23/3/2020.

DOI: 10.11606/0103-2070.ts.2020.166581.

Gustavo Mesquita é doutor em história social pela Universidade de São Paulo com pós-doutorado pela Escola de Ciências Sociais/CPdoc da Fundação Getúlio Vargas. Em 2020, é professor visitante da University of Birmingham, Inglaterra, onde desenvolve estudos sobre o papel do Brasil na descolonização africana. É também autor de artigos e livros, sendo o mais recente, em coautoria com Elizabeth Cancelli e Wanderson Chaves, Guerra Fria e Brasil: para a agenda de integração do negro na sociedade de classes (Alameda, 2020). E-mail: gustavormesquita@gmail.com.

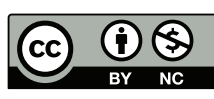

